ROCZNIKI KULTUROZNAWCZE

Tom/Vol. XII, numer/number $2-2021$

DOI: http://doi.org/10.18290/rkult21122-9

IRYNA BALTAZIUK

\title{
THE SACRED IN THE SYMBOLS OF UKRAINIAN PAINTING AT THE TURN OF THE 21ST CENTURY
}

\section{PROBLEM STATEMENT}

The study of the nature of the immaterial in modern science is based on the interdisciplinary methodology of the basic sciences of philosophy, history, psychology, theology, phenomenology, literary studies, art history, and culturology. The concept of the sacred refers to the philosophy of cognition, a science which plays an important role in the work of contemporary Ukrainian artists. Traditions in the interpretation of the faith in contemporary Ukrainian art begin with Kazimir Malevich - the forerunner of the icon of the new century. There is a need to analyze the semantics of contemporary painting, since it gives the visual material that forms the belief of the millennials, which exists on the border of the material and the holy, as a reflection of the unreal world.

There are a number of Ukrainian artists who embody the composition of the work with biblical motifs and elements of divine culture, which are symbols in the iconic order of the picture and enrich its narrative: Mykhailo Zhuk, "White and Black" (1912-1914); Volodymyr Shaposhnikov, "Great Kharkiv Polyptych" (1987); Feodosiy Humeniuk, "Our Saints" (1973), "Ryazheni” (1975), "Snake Fighter" (1978), "Call of Spring” (1990); Mykola Malyshko, "Adam and Eve" (1996); Mykola Storozhenko, "Premonition of Golgotha" (2013); Oleksandr Dubovyk, "The Prophet" (1990-2015), "Mystical Supper" (2005), "Portal" (2013); Petro Bevza, "The Crucifixion" (2007), "To the Light 2" (2012), "Domus VII" (2015); Sergiy Gnoyovyi, "Characteristic" (2011), "Wings of Hope" (2016), and "Black Night" (2018).

IRYNA BALTAZIUK - Post-graduate and PhD student at the National Academy of Fine Arts and Architecture, Kyiv, Ukraine; e-mail: voronairina.v@gmail.com; ORCID: https://orcid.org/ 0000-0003-0188-6096. 
Another group interprets themes, plots, elements, weaving them into a new pattern (social, urban, existential, etc.): Oleksiy And, "Fatality" (1991), "Logic of Illusions" (1993), "Keeper of Symbols" (1998); Oleksandr Roitburd, "Sitting Prophet" (1988), "Commentary on the Torah" (2020), "Heroic Landscape with the Cardinal" (2020), "Psychological Cyclops Portrait" (2020), "The Prophet and the Fish" (2020); Victor Sydorenko, "Reflection in the Unknown" (2013); Yuriy Koval, "Untitled 1" (2018); and Danylo Galkin, "Untitled" (art project "Queer Time") (2012). The third group replaces the meaning of the sacred with the author's reflections, deforms it, plays with concepts, building a discourse with mass culture: Andriy Tsoy, "Observer" (2015), "Sundial" (2015), "Reconstruction" (2016), "Inanitas" (2016), "Cultum" (2016), "Help me Cheesus" (2018), "Forte", "Cardinal" (2020); Dasha Kandynska, “Adam" (2019), "Fashion Icon" (2019); Anastasia Avula, "Savior Not-Made-by-Hands" (2019); Oksana Chepelyk, "Post-Human 1" (2019); Nina Murashkina, "Red Angel" (2017), "Blue Angel" (2019); Lyudmila Rashtanova, "Virgin Mary" (2018); Sergiy Panasenko, "Sale" (2015), "The Crucifixion" (2016); Mykyta Tsoy, "Hashtag" (2017), "Simulator No. 5" (2018).

Focusing on the third group of artists and the transformation of religious symbols into contemporary art, we will address the representatives of each of the outlined groups.

\section{RESEARCH ANALYSIS}

The issue of the sacred is one of the foundations of modern society, which scientists turn to when studying it in terms of history and philosophy (Gerardus van der Leeuw, Mircea Eliade, Sigmund Freud, Georges Bataille, René Girard, Martin Heidegger, Ernst Cassirer, Jacques Lacan, Nikolai Berdyaev), psychology (Carl Gustav Jung, Erich Fromm, Graham Hancock, Aldous Huxley), theology (Paul Tillich, David Moss, Émile Durkheim, Hans Jonas, Mikhail Yampolsky), phenomenology (Max Scheler, Roger Caillois, Rudolf Otto), literary studies (Charles Baudelaire, Stéphane Mallarmé, Georges Bataille, Walter Benjamin, Pierre Klossowski, Jean-Paul Sartre, Maurice Blanchot, André Malraux), art history and cultural studies (Titus Burckhardt, René Girard, Leopold Flam, Wilhelm Worringer, Jacquelyn Kegley). 


\section{OBJECTIVE}

Our objective is to determine the content of the sacred in the symbols of contemporary Ukrainian painting at the turn of the 21st century, as exemplified by works of Oleksandr Dubovyk, Andriy Tsoy, Mykyta Tsoy, and Nina Murashkina. The purpose of my paper is to focus on the transformation of religious symbols into contemporary ones as a result of building a discourse with mass culture, that generate them into a new cultural code.

\section{DISPLAY OF THE MAIN MATERIAL}

The concept of sacrum, which comes from the pre-Christian era, is enshrined in Latin as meaning 'sacred'. Ancient beliefs identified the sacred (which contributed to the emergence of fetishes and totems) with phenomena which cannot be explained. Two opposite meanings were used in the concept of "sacred" - saintly and infernal, majestic and abominable, holy and profane. We also see a binary view of faith in the works of Sergey Zenkin, whobased on the study of Émile Benveniste - distinguished between 'sacer' and 'sanctus' and saw two bases in sacramentality: good and evil. ${ }^{1}$ Thus, for an enlightened person, the metaphysical means truth and for most others myth and anti-sacredness. Thousands of centuries of evolution have not yet deprived humanity of fear of the realness and the post-truth age is only a confirmation of that.

In Mircea Eliade's philosophical texts we see the division into the sacred and the profane, where the latter is described as secular, contrasting a spiritual person with a modern one. Eliade says that the knowledge of ancestors, which is encrypted in archaic symbols, contains knowledge of materiality. For ancient people divine means existing, while for modern ones the impossibility to conceive reality. Therefore, the archaic is identified with the blessed, while modern with the profane. ${ }^{2}$ In his scientific work The Sacred and the Profane, exploring the nature of religion, Eliade emphasizes that the faith is not an

\footnotetext{
${ }^{1}$ Yana OSYKA and Volodymyr MiSHENIN, "Sakralnoye v sovremennoy kulture: podkhody k opredeleniyu i granitsy ponimaniya," Nauchnyye vedomosti. Seriya Filosofiya. Sotsiologiya. Pravo 25, no. 16 (2013): 262.

${ }^{2}$ Mircea EliADE, "The Sacred and the Profane": The Nature of Religion, trans. Willard Trask (New York: Harcourt, 1959), 17-18.
} 
exact reflection of the empirical, but it exists in the dimension of actuality that differs from the real, always manifesting itself as a reality that differs from the ordinary. Thus, assuming the fact that the sacred is not a direct reflection of truth, we can conclude that the fiction of the modern world becomes a reflection of the spiritual and now is a proof of the opposite situation.

"By the highest holy values, which are recognized as the same values in secular life, Christianity defines truth, goodness and beauty." ${ }^{\prime 3}$ It is true that realness is identified with being but with a subjective nature, and like the original beliefs that underlie any theology, truth is revealed only to the prepared mind, remaining beyond reality for the majority. Analyzing Ukrainian religious art in terms of traditions, modernity and perspectives, the Roman monk of Ukrainian origin Parteniy Pavlyk writes: "A work of sacred art cannot be created or interpreted only in an aesthetic way. A sacred work of art should be a vital expression of a person." " Ivan Buylenkov, revealing the nature of the divine according to Victor Turner, writes that its perception is not based on "pragmatic expediency, but on the general system of worldview that functions in this society." This opinion was also held by Émile Durkheim, Arnold van Gennep, Alfred Radcliffe-Brown, Roger Caillois and others. ${ }^{5}$

Art itself underlies this way of finding a thin line between the sacred and the anti-sacred, the realization of that thin boundary which, like a mirror or a transparent membrane, becomes a specular image of actuality, which only at first glance speaks of identity, but is not true in its essence. If light and darkness exist in harmony and organic union with each other, they are of no concern. However, when the balance is disturbed, the world begins to be perceived as non-existent, with a duality of dimensions or meanings that has lost its true dimension. For modern society, such a source of imbalance is the rise of technology, technocentrism, digital life, collective consciousness, globalization, and others. The age of consumption creates new idols, where the icon loses its sanctity, the dialogue with the material world turns the

\footnotetext{
${ }^{3}$ Yuriy KRYVORUCHKO, "Mezhi sakralnoho: vyklyky dlia mystetstva," Patriarkhat, no. 2 (2019), http://patriyarkhat.org.ua/mezhi-sakralnoho-vyklyky-dlya-mystetstva.

${ }^{4}$ Parteniy PAVLYK, "Ukrainske sakralne mystetstvo: tradytsii, suchasnist, perspektyvy," in Ukrainske sakralne mystetstvo: tradytsii, suchasnist, perspektyvy: materialy mizhnar. nauk. konf. (Lviv, Ukraine, May 4-5, 1993), ed. Emmanuyil Mysko (Lviv: Svichado, 1994), 97.

5 Ivan BUYLENKOv, "Ponyatiye sakralnogo v kontseptsii kultury Viktora Uittera Ternera," in Pivovarovskiye chteniya. Sinteticheskaya paradigma: nauka, filosofiya, religiovedeniye: sbornik materialov konferentsii (Ekaterinburg: Delovaya kniga, 2019), 323.
} 
private into the public, and the sanctified nature of inner being becomes material and the miracle becomes everyday life.

One of the most striking examples of a modern icon and at the same time an echo of iconoclasm is the "Black Square" (1915) by the avant-garde artist Kazimir Malevich. The author created this "myth" when more than a hundred years ago he presented the "Black Square" to the public in the way that our ancestors and the whole Slavic culture honored icons, placing the artwork in the so-called "red corner" of the exhibition space. Icons used to be placed in the right-hand corner of the house called the "red corner" and at that time there was a habit and a ritual for most people of this culture (which was actually used by Malevich) to enter the room while first looking to the right. In this way, the artist made the audience feel horror and surprise while playing on instinct as the basic emotion of every living being. He planted the seeds of an idea that could not be done away with. A habit is an important, or even the basic element of existence. When almost every visitor entered the room, looked to the right where the "Black Square" was exhibited, instinctively raising his hand to cross himself or herself, felt what is called a reflex reaction. The feeling is like a burn, but an emotional one, after which there was no doubt that the world is waiting for a distorted unreal actuality, where new idols and icons will exist, without which modern man cannot imagine his life, and at the same time lose all truth and the sacred that can be found inside. There is a replacement of one icon with another, but in contrast to the first one (which had a holy source) the latter depicts a sacred void.

The prominent Ukrainian avant-garde artist Oleksandr Dubovyk, the author of the "bouquet," should be singled out in the creation of a new sign that broadcasts the dialogue with Malevich, who has a national character. Dubovyk says: "The square is also a sign, the first stone of existence.... Malevich, in fact, said: 'Art begins with me. Behind the square there is emptiness, and everything that happens in it is nothing'. I have the opposite: the bouquet is an absolute fullness, a mass in which all concepts and meanings are concentrated." Contrasting his bouquet with the black square, Dubovyk declares the Ukrainian ethnic group with its features - the bouquet, which is a "sign of the Ukrainian idea," this is the concept that fills with exultance, because the

\footnotetext{
${ }^{6}$ Anna Sherman, "Novaya mifologiya Aleksandra Dubovika," Antikvar, no. 7-8 (2016): 38-39.
} 
national cultural symbol must be powerful and gain the ability of creation. Bouquet as an idea "is not filled with evil but displaces it.",

The desire to find the original myth has colored Dubovyk's bouquets since the end of the 20th century. His works are an archive for future generations, and an archive is a code. The original archaic symbol of "shadow" in the work "Play" (1979) is the shadow of a bouquet, a tree of life according to Dubovyk, which is presented as a portal through the symbol of "reflection." All lines converge to the point of growth and the beginning of the energy flow, so the author visualizes connection and information channel of ancestral experience. If we talk about the general cultural phenomenon, then such a point of growth, the center of national and world energy is modern spirituality. Yana Osyka and Volodymyr Mishenin, who, while studying the sacred as a phenomenon of modern culture, formed the opposition sacred-secular and secular-postsecular, conclude that a symbolic manifestation as a point of coincidence of all known concepts is inherent in the foundation of world ancient and modern philosophical thought of the sacred idea. ${ }^{8}$ The question of the universe and space has always interested the author, so in this aspect the work "Play" is characteristic, because it depicts the process of information transfer between Earth and space. In the era of information overload, the artist thinks that conciseness and accuracy are especially important, both in painting and in literature, because the message must touch on painful topics and strike instantly.

The work of the famous Ukrainian artist Andriy Tsoy, and the classic of the art world Oleksandr Dubovyk, is also a bouquet - a bouquet of postmodernism, which combines all the noted and newly created symbols of mass culture. "With his works, the author demands satisfaction from modern society, morality and religion, criticizes information cannibalism and 'fake', namely the fake of today's reality." In the work "Cultum" (2016) the artist vividly represents the duality of the world from the project "Fetish," in the sacredness of the consumer era, fetish brands and new gods such as Mickey

\footnotetext{
${ }^{7}$ Svitlana Agrest-Korotkova and Oleksandr DubovyK, "I keep putting together the jigsaw puzzle of my picture of the world," Den, Nov. 7, 2017, accessed May 11, 2020, https:// day.kyiv.ua/en/article/culture/oleksandr-dubovyk-i-keep-putting-together-jigsaw-puzzle-mypicture-world.

${ }^{8}$ OSYKA and MishCENIN, "Sakralnoye v sovremennoy kulture," 267.

9 “"Help me Cheesus': nova vystavka Andriia ta Mykyty Tsoia," ArtUkraine, November 2, 2018, accessed April 11, 2020, artukraine.com.ua/n/help-me-cheesus--nova-vistavka-andriyata-mikiti-coya/\#.XpGorfj7RPY.
} 
Mouse and Louis Vuitton. The archaic symbol of cross loses its scriptural origin in the works of Tsoy; now it is rather a symbol of the absence of God and its identity refers to computer symbolism and the world of new "Gods." The metal disk that hides the eye speaks of the artificial perception of the world through gadgets that transmit a reality distorted by manipulation. The favorite scheme of artists of the new century is a half-hidden face, as a result raising the question of identity, loss in the dimension of new knowledge, information and globalization. The inner "I" is lost, it is obscurely who you are, but the part of you that is clearly visible reflects all the symbols of mass culture. A similar technique was used by the young artist Dmytro Zazymko in the work "Mickey Mouse Buddha story" (2020), depicting the modern idol Mickey Mouse in the vision of the Buddha, therefore showing the depth of human faith in modern idols. Exactly in the equating of mass culture to the spiritual principle of human beings lies the source of erosion, which destroys true values, replacing them with artificial ones.

Intersubjectivity and the distorted sacred are reflected in the joint project of Andriy Tsoy and Mykyta Tsoy titled "Help me Cheesus" (2019), which also combines duality and psychedelics. "Help me Cheesus" is associated at first glance with the phrase "Help me Jesus" and a request for help, but it is rather a view on religion through the eyes of millennials. The word "Cheesus," meaning "cheese Jesus," is taken from the episode "Grilled Cheesus" (2010) of the American television series "Glee," which talks about the balance of belief and atheism, the issues of today's society that are often addressed by Mykyta Tsoy in his works. The modern American film industry, and comics as well, is a significant part of the influence on the work of young artists, which manifests the mentality of the individual in the 21 st century. "I see the world through the artificial multi-brand content, so I think that the series will help to portray the whole essence and get rid of unnecessary drama," reveals Tsoy. ${ }^{10}$ The current topics addressed by the author in the projects "Help me Cheesus" and "Hamperdu," created under the influence of the series "Preacher" are also related to the spirituality of modern society.

Contemporary art, while translating social consciousness as its own, becomes the bare nerve of the deepest problems of cognition. In each of his series, Andriy Tsoy tries to find this connection with the wisdom of ancestors,

\footnotetext{
${ }^{10}$ Tatiana TOLSTYKH, "Serial i nazvaniye bez spoylerov: kiyevskiy khudozhnik rasskazal sekrety svoyey vystavki," 44.ua, February 7, 2019, accessed February 7, 2019, 44.ua/news/ 2298368/serial-i-nazvanie-bez-spojlerov-kievskij-hudoznik-rasskazal-sekrety-svoej-vystavki.
} 
which will make it possible to comprehend the core of the existence of modern humanity, going through the whole symbolic range of world sacredness from the original sources to the present. When the mind is faced with an impossible task, it seeks to explain the mysterious essence of things in a rational way. That is why works with the idea of constructive creation appear in the artist's practice. In such works - with the concept of "construction" - as "Septenary construction of the world" (2015), "Observer" (2015), "Sundial" (2015), "Reconstruction" (2016), and others, Tsoy seeks to understand the mechanism of the universe, to analyze how everything is arranged, to find a formula and to learn an algorithm. In each of these and most other works of Tsoy we can see mechanisms and complex details as part of the overall system since the author speaks in a technical way of the philosophical thought of the world creation. The artist visualizes the method of analysis and synthesis in painting, as a desire to understand the internal system of interaction of parts of the whole, a method later used by his son Mykyta in the art project "Hashtag" (2017), which divides the inner "I" into segments to collect these fragments into one piece after all. Now we see that the division of consciousness into parts the philosopher Nicolai Berdyaev wrote about and which Mykyta began to visualize speaks about the illusory nature of true life and the unreality of modern human way of thinking.

Mykyta Tsoy's project "Hashtag" depicts this state of unique impersonality where the artist in search of the hashtag of the day creates a series that cuts life into segments. "Dividing and rapid separation of feelings were only more misleading, offering several options of themselves," admits the author. ${ }^{11}$ In this project, the artist was interested not in the result but in the process, because "each artwork began and ended almost on the same day, thus determining the momentary subconscious and became the tag of the day." Segments of one's own "I," such as \#zzz, \#boo, \#bag, \#doll, capture emotions from each day. The modern world dictates the predominance of emotional intelligence, where each individual is unique, as are his emotions, so now people are more focused on their own inner world, their own emotions and experiences - this glorifies the individual to a unique unit and at the same time creates an era of selfish thinking, immersed in himself.

\footnotetext{
11 “Nikita Tsoy 'zzz boo bag doll'," Facebook, 28 April 2017, accessed May 12, 2019, www.facebook.com/events/концепт-лаборатория-артерия/никита-цой-zzz-boo-bag-doll/30 1719893574417.
} 
The symbol \#, known as "hashtag" or "lattice," appeared more than two centuries ago, long before it became popular in 2007 as a symbol widely used in social networks for quick search and was recognized as the word of the year by the Oxford Dictionary in 2012. Its primary significance was related to medicine, since in prescriptions this symbol separated the names of drugs. The sign \# was mentioned in the texts of the medical field, as "the medieval symbol of the words 'Cum Deo', with which the prescription began."12 Therefore, the modern symbol \# has a divine origin, because "cum Deo" means "with God." The relation to the symbol of cross is also in one of the many meanings of theological symbol - to indicate the location of the thing and to be a mark. In this way, in the work "Hashtag" (2017) and all series of the same name, Tsoy gives the ancient religious symbol a profane meaning. As the author himself says, the hashtag is the key, which helps to quickly find access to the object, but complicates the search for truth, because it is not known which of them hides the true personality.

We see a consonant notion in the work "Forte" (2017) by Andriy Tsoy, where the cyclicity of time is presented through the symbol of an arrow in a dynamic circle motion, which returns time repeatedly to the static point where the main character of the artwork exists. The arrow is an ancient symbol of holiness, light, and attributes of Gods. Since ancient philosophy the arrow has been a metaphor of time, "the famous paradox of Zeno 'Arrow'. The Greek logician argued that the flying arrow remains at the same time ... in a static state." 13 Rethinking the matter of the spiritual and the archaic in the symbol of arrow, Andriy Tsoy refers to the ability of this sign to speak about the movement of time while remaining constant.

The search for reality is a living path in which an intellect guided only by rational thinking and not endowed with an enlightened source will pass with no result. It is a path that can last forever, and truth will continue to exist on the horizon of events, which can be approached indefinitely. This is the same cyclical arrow setting by Tsoy in the work "Forte," which will never reach the goal, because it will move indefinitely in the circle of knowledge. "Being is given to the rationalistic dissection of the spirit and to the bifurcation into subject and object. The division into subject and object of being is given only

\footnotetext{
${ }^{12}$ Konstantin SHMELEv, Retsepturnyy spravochnik dlya nachinayushchego vracha, 2nd ed. (Saratov: Saratovskoye blastnoye gosudarstvennoye izdatelstvo, 1942), 3.

13 "Strila," in Slovnyk symvoliv, ed. Oleksandr Potapenko et al. (Kyiv: Narodoznavstvo, 1997), accessed October 11, 2020, studfile.net/preview/5252915/page:18.
} 
in a religious, mystical experience."14 The Ukrainian artist Nina Murashkina is one of those, who in an attempt to inject spirituality into the modern bifurcated personality, tries to look beyond the horizon of events: "Red Angel" (2017), "Triumph of justice" (2018), "New Leda" (2018), "Mirror" (2019), "Blue Angel" (2019), etc. All her art and each artwork itself is a mirror of sacredness, in which the artist repeatedly divides the personality into light and darkness in search of honesty. A thin line that separates actuality from myths, exists on the surface of her philosophy, like a thin thread that reemerges after disappearing. Murashkina endows her characters with the metaphysical realism, thanks to which her works look like an ancient altar which opens to the prepared mind only in the moment of true belief. In search of a form to express the entity of her idea, Murashkina, together with her husband, a sculptor from Spain by the name Xavier Escala, creates a real altar of the modern human's consciousness, multiplied by the archaic creed - to reveal sincerity to the viewer.

The celebration of justice and the apotheosis of true life is recreated by Murashkina in her "Triumph of Justice" (2018), in which the mirror of faith is embodied in the bifurcation into subject and object. In this work, as well as in the work "Forte" by Andriy Tsoy, there is cyclicality, but in contrast to his arrow, Murashkina uses a woman's hand, which is less symbolic than an arrow, but more devotional. Symbolism is synonymous with the sacred, but in this example, we see that symbolism can gravitate to both the rational and the immaterial. Tsoy's symbolism is transmitted through a truly masculine desire for logical thinking and rational explanation of the essence of things, while Murashkina uses the feminine principle, which is known to be endowed with the blessed source. Her symbolism tends to the spiritual dimension, and although the hand of a woman is not the hand of the creator, it has the power of ancient knowledge, that is so necessary in the way of understanding the truth. Magical realism in her works combines: the archaic, which is so lacking in the modern world; Christian symbolism, but without rational artificial thinking, which is what the enlightened mind desires in existence perception; connection with ancestors, which is a collective final element in the search of reality. The woman in "Triumph of Justice" is both a subject and an object at the same time, one side of which holds the light, but it will never appear to the other side, because it is existing truth, which will never appear. Translating

\footnotetext{
${ }^{14}$ Nikolai BerdyAev, Filosofiya svobody (Moskva: Put, 1911), 20.
} 
through painting what the modern philosophical thoughts strive for trying to return the lost paradise of true existence in the struggle against Kant's rationalism, Murashkina approaches the truth. Her heroines smile with their pre-Christian smile, so the viewer can only smile back at them, taking a step towards meeting knowledge.

\section{CONCLUSION}

The symbolism of contemporary art absorbs the most characteristic signs, codes and ciphers of previous centuries, the source of which is archaic, generating them into a new cultural code understandable to most people. Thus, in the conventional sense, the once sacred becomes profane. Searching for the answers to the question what is the sacred in modern society, Ukrainian artists form a dialogue with Kazimir Malevich, a famous avant-garde artist of Polish and Ukrainian origin and the author of the icon of the 21st century. The most remarkable example of this dialogue is formed in the works of Oleksandr Dubovyk, Oleksandr Roitburd and Oleksandr Klymenko. In contrast to Malevych's "Black Square," as an idea of emptiness, contemporary Ukrainian artists strive to create art that holds the fullness of nature. In this way, they are helped by the heritage of the Ukrainian ethnos, which harmoniously combines the memory of Trypillia culture, national symbols, traditions of icon painting, the school of Mykhailo Boychuk and much more. Through the symbols of mirror, mirroring and reflecting, which have an ethereal basis, the contemporary artworks transfer spirituality into the 21 st century, with all its fears, disturbance, and continuous search within the individuality. A striking example is the art of Nina Murashkina, because the main heroine of her artwork is a 21 st-century person-Mother-Earth in which archaic Christianity and modern anti-sacredness are combined. Works of art of Andriy Tsoy and Mikita Tsoy mirror modern religion, which reflects all the symbols of mass culture, as a bouquet of postmodernism, which also continues the path of dialogue with Malevich, begun in the 20th century by Ukrainian artists.

Divine symbols such as the cross, eye, arrow, and woman are gaining new relevance. However, if we take into consideration today's spirituality, which - despite its opposite manifestation to the religious one - has the power to influence the formation of individuality, and therefore, we cannot say that the symbols attain a profane meaning, losing their holy source. Since modern man treats his own experience as sanctified, the symbols of contemporary art 
receive the color of modern spirituality, which is becoming more and more influential in millennial's way of thinking. The utopian world of the philosophy of life in which religion and mysticism harmoniously exist in the basis of his theory of the life realism of the truth of being, for modern human is only a myth, which is illusory as the light of a long-extinguished star.

But still, the emptiness left by Kantian realism - which destroys the connection with the roots of existence, eliminates its energy, leaving humans devastated - is filled now with the source power of a new wave of return to non-material mysticism, pagan beliefs, and pre-Christian teachings of Mother Earth. This path leads to the revival of sacredness, which must find the lost realism, but in a completely different form.

\section{BIBLIOGRAPHY}

Agrest-KorotKova, Svitlana. "Oleksandr Dubovyk: I keep putting together the jigsaw puzzle of my picture of the world." Den, Nov. 7, 2017. Accessed May 11, 2020. https:// day.kyiv.ua/en/article/culture/oleksandr-dubovyk-i-keep-putting-together-jigsaw-puz zle-my-picture-world.

Berdyaev, Nikolai. Filosofiya svobody. Moskva: Put, 1911 | Бердяев, Николай. Философия свободы. Москва: Путь, 1911.

BUYLENKOv, Ivan. "Ponyatiye sakralnogo v kontseptsii kultury Viktora Uittera Ternera." Pivovarovskiye chteniya. Sinteticheskaya paradigma: nauka, filosofiya, religiovedeniye: sbornik materialov konferentsii, 322-24. Ekaterinburg: Delovaya kniga, 2019 | Буйленков, Иван. «Понятие сакрального в концепции культуры Виктора Уиттера Тернера». Пивоваровские чтения. Синтетическая парадигма: наука, философия, религиоведение: сборник материалов конференщии. Екатеринбург: Деловая книга, 2019.

Eliade, Mircea. The Sacred and the Profane: The Nature of Religion. Translated by Willard Trask. New York: Harcourt, 1959.

“'Help me Cheesus': nova vystavka Andriia ta Mykyty Tsoia | «Help me Cheesus»: нова виставка Андрія та Микити Цоя." ArtUkraine, November 2, 2018. Accessed April 11, 2020.artukraine.com.ua/n/help-me-cheesus--nova-vistavka-andriya-ta-mikiti-coya/\#. XpGorfj7RPY.

KrYvorUChKo, Yuriy. "Mezhi sakralnoho: vyklyky dlia mystetstva." Patriyarkhat, no. 2 (2019) | Криворучко, Юрій. “Межі сакрального: виклики для мистецтва.” Патріяpxam, № 2 (2019). Accessed October 2, 2020. http://patriyarkhat.org.ua/mezhi-sa kralnoho-vyklyky-dlya-mystetstva.

"Nikita Tsoy 'zzz boo bag doll'." Facebook, 28 April 2017. Accessed May 12, 2019. www.facebook.com/events/концепт-лаборатория-артерия/никита-цой-zzz-boo-bagdoll/301719893574417.

OSYKA, Yana, and Volodymyr Mishenin. "Sakralnoye v sovremennoy kulture: podkhody k opredeleniyu i granitsy ponimaniya." Nauchnyye vedomosti. Seriya Filosofiya. Sotsiologiya. Pravo 25, nо. 16 (2013): 262-67 | Осыка, Яна, Владимир Мишенин. «Сакральное в современной культуре: подходы к определению и границы 
понимания». Научные ведомости. Серия Философия. Социология. Право 25, № 16 (2013): c. 262-267.

PAVLYK, Parteniy. "Ukrainske sakralne mystetstvo: tradytsii, suchasnist, perspektyvy." In Ukrainske sakralne mystetstvo: tradytsii, suchasnist, perspektyvy: materialy mizhnar. nauk. konf. (Lviv, Ukraine, May 4-5, 1993), edited by Emmanuyil Mysko, 95-101. Lviv: Svichado, 1994 | Павлик, Партеній. «Українське сакральне мистецтво традиції, сучасність, перспективи». В Українське сакральне мистецтво: традиції, сучасність, перспективи: матеріали міжнар. наук. конф. (Львів, 4-5 трав. 1993), за ред. Еммануїл Мисько, с. 95-101. Львів: Свічадо, 1994.

"Strila". In Slovnyk symvoliv. Edited by Oleksandr Potapenko et al. Kyiv: Narodoznavstvo, 1997 | «Стріла». В Словник символів. За ред. Олександра Потапенка та ін. Київ: Народознавство, 1997. Accessed October 11, 2020.studfile.net/preview/5252915/ page: 18 .

Sherman, Anna. "Novaya mifologiya Aleksandra Dubovika." Antikvar, no. 7-8 (2016): 36-43 | Шерман, Анна. «Новая мифология Александра Дубовика». Антиквар, № 7-8 (2016): c. 36-43.

SHMelev, Konstantin. Retsepturnyy spravochnik dlya nachinayushchego vracha. 2nd ed. Saratov: Saratovskoye oblastnoye gosudarstvennoye izdatelstvo, 1942 | Шмелев, Константин. Рещептурный справочник для начинающего врача. Издание 2-е, исправленное и дополненное. Саратов: Саратовское областное государственное издательство, 1942.

TOLSTYKн, Tatiana. "Serial i nazvaniye bez spoylerov: kiyevskiy khudozhnik rasskazal sekrety svoyey vystavki | Сериал и название без спойлеров: киевский художник рассказал секреты своей выставки." 44.ua, February 7, 2019. Accessed February 7, 2019. 44.ua/news/2298368/serial-i-nazvanie-bez-spojlerov-kievskij-hudoznik-rasskazalsekrety-svoej-vystavki.

\section{THE SACRED IN THE SYMBOLS OF UKRAINIAN PAINTING AT THE TURN OF THE 21ST CENTURY}

\section{S u m m ary}

Contemporary art as a measure of social consciousness becomes a reference point for finding the boundary between the sacred and the anti-sacred, the aspect that acting as a mirror becomes a reflection of reality, and only at first glance, it speaks of identity but is not true in its essence. Through the semantic key of the symbols of mirroring and reflecting, in the knowledge of the true picture, from divine emptiness to holy fullness, a dialogue of contemporary Ukrainian artists with Kazimir Malevich is formed. The most powerful example of this dialogue is created in the works of Ukrainian classics Oleksandr Dubovyk, Oleksandr Roitburd, and Oleksandr Klymenko. On this path, artists are helped by the heritage of the Ukrainian ethnos, which harmoniously combines the memory of Trypillia culture, national symbols, traditions of icon painting, the school of Mykhailo Boychuk and much more. This article focuses on the sacred in the symbols of contemporary Ukrainian painting that absorbs the most characteristic signs, codes, and ciphers of the previous centuries, transferring spirituality into the 21 st century. The transformation of religious symbols into contemporary ones, in consequence of building a discourse with mass culture, generates them into a new cultural code. The semantics of mass culture gives the visual material that forms the sacredness of the 21 st century, which exists on the border of the material and the spiritual, as a reflection 
of the myth. The works of art by Nina Murashkina, Andriy Tsoy, and Mykyta Tsoy are a striking example of that. The sacred in which the mystery of real life is concentrated can endow thinking with a true, rather than an imaginary essence and provide a tool for solving the problem of individuality, freedom, and existence, which the new century is filled with.

Keywords: contemporary art; symbol; sacred; truth; artwork; artist.

\section{SACRUM W SYMBOLICE MALARSTWA UKRAIŃSKIEGO NA PRZEŁOMIE XX I XXI WIEKU}

\section{Streszczenie}

Sztuka współczesna jako miara świadomości społeczeństwa staje się punktem odniesienia dla zlokalizowania granicy między sacrum a anty-sacrum — aspektem, który, działając jak lustro, staje się odbiciem rzeczywistości i tylko na pierwszy rzut oka opisuje tożsamość, ale w swej istocie nie jest prawdziwy. Poprzez klucz semantyczny zawarty w symbolice lustra i odbicia, w poznaniu prawdziwego obrazu, od boskiej pustki do świętej pełni, następuje dialog współczesnych artystów ukraińskich z Kazimierzem Malewiczem. Najdobitniejszym przykładem tego dialogu są prace ukraińskich klasyków Ołeksandra Dubowyka, Ołeksandra Roitburda i Ołeksandra Kłymenki. W tej drodze artystom pomaga dziedzictwo ukraińskiego etnosu, które harmonijnie łączy pamięć kultury trypolskiej, symbole narodowe, tradycje malarstwa ikonowego, szkołę Mychajły Bojczuka i wiele innych. Prezentowany artykuł skupia się na sacrum w symbolice współczesnego malarstwa ukraińskiego, które wchłania najbardziej charakterystyczne znaki, kody i szyfry poprzednich stuleci, przenosząc duchowość w XXI wiek. Transformacja symboli religijnych na współczesne, a w konsekwencji budowanie dyskursu z kulturą masową, tworzą nowy kod kulturowy. Semantyka kultury masowej dostarcza materiału wizualnego, który tworzy sakralność XXI wieku, istniejącą na granicy tego, co materialne i duchowe - jako odbicie mitu. Dzieła sztuki Niny Muraszkiny, Andrija Tsoya i Mykyty Tsoya są tego dobitnym przykładem. Sacrum, w którym skupia się tajemnica prawdziwego życia, sprawia, że myślenie jest czymś realnym, dostarczając narzędzia do rozwiązania współczesnego problemu indywidualności, wolności i istnienia.

Słowa kluczowe: sztuka współczesna; symbol; sacrum; prawda; dzieło sztuki; artysta. 